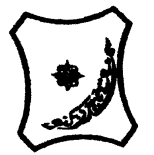

Bayero Journal of Pure and Applied Sciences, 10(1):268 - 276

Received: November, 2016

Accepted: April, 2017

ISSN $2006-6996$

\title{
SEASONAL DYNAMICS OF ZOOPLANKTON COMPOSITION AND ABUNDANCE IN THOMAS DAM DAMBATTA, KANO, NIGERIA
}

\author{
${ }^{1}$ Nafi'u, S.A. and ${ }^{2}$ Ibrahim, S. \\ ${ }^{1}$ Department of Science Laboratory Technology, Kano State Polytechnic, Kano \\ ${ }^{2}$ Department of Biological Sciences, Bayero University, Kano \\ Corresponding author: nafiune.sn@gmail.com, 07030918094
}

\begin{abstract}
Seasonal dynamics of zooplankton composition and abundance as influenced by physicochemical parameters of Thomas Dam were studied between January and October, 2016. Zooplankton and water samples for physicochemical parameters were collected and analyzed fortnight/y between 8:00 - 10:00 am using standard methods. Four sampling sites (A, B, $C$ and $D)$ were chosen on the Dam based on the vegetation pattern and impact of human activities. The mean range of physicochemical parameters studied were temperature $\left(18.5-28.9^{\circ} \mathrm{C}\right), \mathrm{pH}(7.5-8.9), \mathrm{DO}(4.8-$ $9.1 \mathrm{mg} / \mathrm{L}), \mathrm{BOD}(2.2$ - 4.9mg/L), turbidity (16.3 - $37.1 \mathrm{NTU})$, electrical conductivity (131.8 $335.7 \mu \mathrm{S} / \mathrm{cm})$, TDS $(140-386.6 \mathrm{mg} / \mathrm{L})$, phosphate $(0.15-1.13 \mathrm{mg} / \mathrm{L})$ and nitrate $(0.14-4.78 \mathrm{mg} / \mathrm{L})$. Total dissolved solids, electrical conductivity, turbidity and nitrate recorded significant difference between wet and dry season $(P<0.05)$. While no significant difference was observed between DO, BOD, phosphate, temperature and pH. Thirty two (32) species of zooplankton were identified belonging to Protozoa (4.3\%), Cladocera (42.0\%), Rotifera (29.6\%) and Copepoda (24.1\%) which accounted for $268.50 \mathrm{rg} / \mathrm{L}$ of the total faunal composition. Site $A$ had the highest zooplankton density of $80.90 \mathrm{rg} / \mathrm{L}$ while site $C$ recorded the least with $69.7 \mathrm{org} / \mathrm{L}$. Daphnia pulex had the highest species composition of $9.330 \mathrm{rg} / \mathrm{L}$ and Pleuronema sp. recorded the least with $0.070 \mathrm{rg} / \mathrm{L}$. Seasonal variation indicated a strong positive relationship between physicochemical and zooplankton densities (P<0.05). Biotic Indices analyses of Shannon-wiener Index, Evenness Index and Margalef's Index showed that zooplankton composition and abundance were highest during wet season than in dry season. However, Pearson Correlation Coefficient between zooplankton abundance and physicochemical parameters indicated strong positive relationship at $p<0.01(2-$ tailed). The composition and abundance of zooplankton in Thomas Dam were affected by seasonal variation and fluctuation of physicochemical parameters during the study period. It is therefore recommended that uncontrolled discharge of agrochemicals around the Dam through irrigation and other human activities should be controlled in order to curtail degradation of the aquatic biota over a period of time.
\end{abstract}

Key words: Seasonal dynamics, Physico-chemical parameters, Zooplankton composition, Diversity, Thomas Dam

\section{INTRODUCTION}

Zooplanktons are the heterotrophic animal component of plankton floating in water body and found either at or near the surface of water bodies (Kusuma et al., 1988). They graze on primary producers and on organic debris in the water column and thereby play an important role in the integration of energy budget of the ecosystem (Anene, 2003). Zooplanktons are useful indicators of future fisheries health and survival because they are a food source of organisms at higher trophic levels (Davies et al., 2009). They help in regulating algal productivity through grazing and in the transfer of energy to fish and other consumers (Dejen et al., 2004).

The abundance and species composition of zooplankton are used to assess the biological integrity of the water body thus removing just one species from an ecosystem may damage the flow of energy in that system (Verma and Agarwal, 2007).Suresh et al. (2011) reported that different environmental factors that determine the characters of water have great importance upon the growth and abundance of zooplankton. Thus, water quality influences zooplankton abundance, clustering and biomass. Distribution of zooplankton in the dams is influenced by abiotic and biotic factors interaction although most species exist under wider range of environmental condition; certain species are limited by temperature, dissolved oxygen, salinity and other physical and chemical characteristics of the water (Ekwu and Sokoki, 2005).

Previous documented studies on the effects of environmental variables on the composition, diversity, abundance and distribution of zooplankton includes, the works of Ibrahim (2009) in Challawa River, Kano; Abubakar et al. (2012) in Nguru Lake, Imam and Balarabe (2012) in the Bompai-Jakara catchment basin; Hassan et al. (2013) in Kanye Dam and Kutama et al. (2014) in Kusalla Reservoir.

In northern Nigeria, reservoirs, ponds, rivers and ground waters are used for domestic and agricultural purposes (Hassan et al., 2013). 
Bajopas Volume 10 Number 1 June, 2017

The study of zooplankton has been very extensive in large rivers and lakes in Nigeria (Ekwu and Sokoki, 2005). Less attention has been given to smaller water bodies which are scattered all over the country and contain a significant proportion of the nation's aquatic biodiversity (Lamai and Kolo, 2003). In view of the foregoing this research aimed at investigating the zooplankton species composition and diversity in relation to seasonal changes in the Thomas Dam Dambatta, Kano -Nigeria

\section{MATERIALS AND METHODS \\ Study Area}

Thomas Dam is located within Sudan savannah zone of Nigeria $\left(12^{\circ} 1644^{\prime \prime} \mathrm{N}-21^{\circ} 18^{\prime} 35 \mathrm{~N}\right.$ and $8{ }^{\circ} 30^{\prime} 5^{\prime \prime} \mathrm{E}-$ $8^{\circ} 31^{\prime} 34^{\prime \prime} \mathrm{E}$ ) with two distinct wet and dry seasons. The rainy season lasts from May to October and dry season runs from November to April (Shitu, 2006). The Dam is about 585 square meters, while its depth is about $30 \mathrm{~m}$. The dam is sited near Danmarke village of Dambatta Local Government area of Kano State, $30 \mathrm{~km}$ away from the ancient Kano City (Kutama et al., 2013).

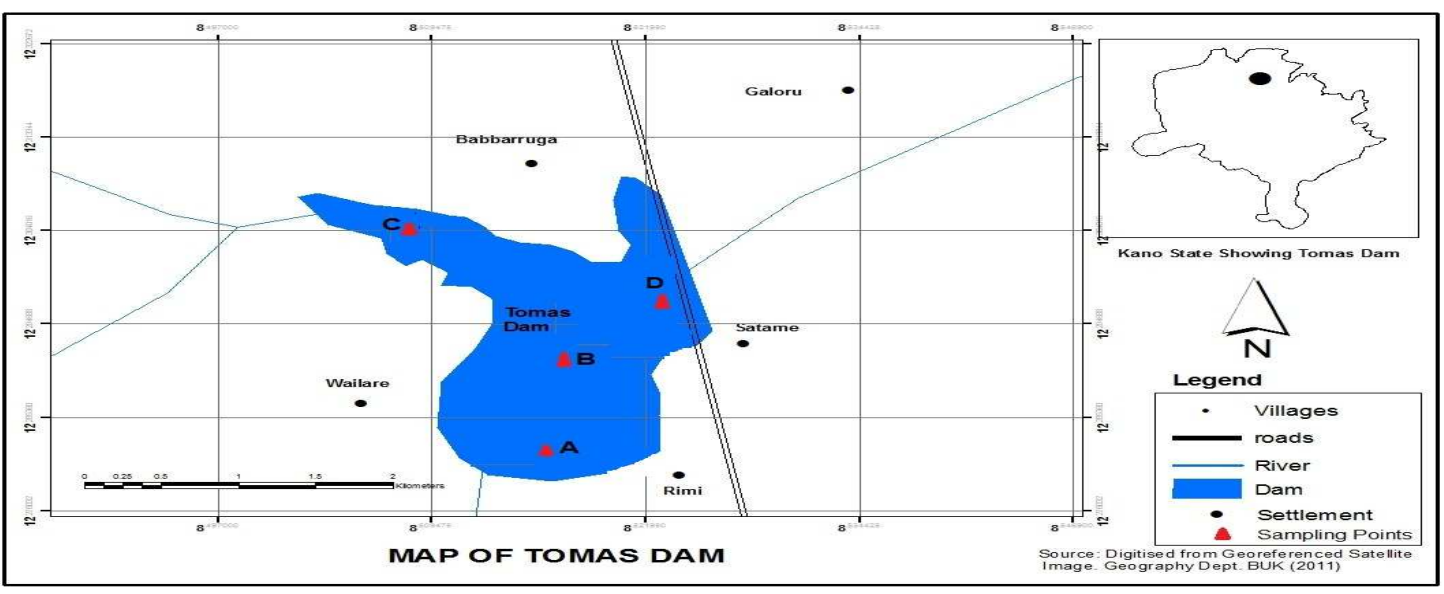

Figure 1: Thomas Dam, Kano State with Marked Sampling Sites

Source: Google Earth (2016).

\section{Sampling Sites}

Four (4) sampling sites were chosen for the purpose of this study and designated as A, B, C, and D on the water course of the dam. The choice of the sites was based on the ecological setting of the sampling area.

Site A: Southern part of the dam $\left(12^{\circ} 16^{\prime} 07^{\prime \prime}, \mathrm{E}\right.$ $\left.8^{\circ} 31^{\prime} 06\right)$; it is one of the shallow parts of the dam; irrigation activities take place during the dry season. Vegetation are subjected to chemicals input from fertilizer application.

Site B: This site (N12 $17^{\prime} 32^{\prime \prime}$, E $\left.8^{\circ} 31^{\prime} 07^{\prime \prime}\right)$ is the mid shore of the dam where there are less human activities apart from fishing.

Site C: This site $\left(\mathrm{N} 12^{\circ} 18^{\prime} 16^{\prime \prime}\right.$, E $\left.8^{\circ} 31^{\prime} 30^{\prime \prime}\right)$ is the entrance of the oases which supply water to the dam. Site D: At this site $\left(\mathrm{N} 12^{\circ} 18^{\prime} 28^{\prime \prime}\right.$, E $\left.8^{\circ} 30^{\prime} 40^{\prime \prime}\right)$, human activities like washing and bathing take place. The water here is partially contaminated with mainly detergent from car, motor cycle washings and other laundry activities.

Determination of Physicochemical Parameters Water Samples were collected fortnightly for a period of ten months (January - October, 2016). The samples were collected from four sampling stations (Site A, B, C and D) between the hours of 8:00 am 10:00am. The following physiochemical parameters were determined as described by APHA (2005): Surface water temperature, Total Dissolved Solids, $\mathrm{pH}$, Dissolved Oxygen, Biochemical Oxygen Demand ${ }_{5}$, Turbidity,Electrical Conductivity, Nitrate - Nitrogen and Phosphate - phosphorus.

\section{Collection and Identification of Zooplankton Samples}

Samples of zooplankton were collected using plankton net of $15 \mathrm{~cm}$ diameter and mesh size $70 \mu \mathrm{m}$ according to the procedure described by Verlencar and Desai (2004).The samples were immediately preserved with $5 \%$ formalin (Wetzel and Likens, 2000). The volume of water that passed through the net was estimated by using the formula described by Goswami (2004). The collected samples were condensed to $10 \mathrm{mI}$ and $1 \mathrm{ml}$ of the zooplankton subsample was withdrawn for sorting and counting using light microscope (Olympus) and camera microscope (LEICA DM 2500 model). Identification of thezooplankton to species level was done using keys described by Lynne (2004), Sanet et al. (2006) and Suthers and Rissik (2009) while counts were made in triplicates and their averages were taken and expressed as org/L. Zooplankton abundance was estimated using the formula as described by Nlewadim and Adeyemo (1998).

$\mathrm{V}=n \mathrm{r}^{2} \mathrm{~d} \quad$ Where $\mathrm{V}=$ volume of water filtered through the net, = radius of the mouth of the net and $d$ = length of the haul (Goswami, 2004)

$\mathrm{A}=Y Z /$ ax; Where, $\mathrm{A}=$ Average plankton per litre, $\mathrm{Y}$ $=$ Average plankton per sample, $Z=$ Concentrate volume $(\mathrm{ml}), \mathrm{a}=$ original volume of sample per liter, $\mathrm{x}$ $=$ Volume of sample or counting chamber examined (ml) 


\section{Determination of Biotic Indices}

Shannon-Weaner (1949) diversity index (H) and species richness was used to determine the phytoplankton species composition and abundance. Shannon-Weaner's Index $(H)$ is commonly used to characterize species diversity in aquatic community.

Shannon-Weaner's Index accounts for both abundance and evenness of the species present. The Shannon - Weiner equation is as follows:Shannon diversity index $\left(\mathrm{H}^{1}\right)=-\sum_{i=1}^{S} \boldsymbol{P i I n P i}$ Where $\mathrm{pi}=$ the proportion of the $\mathrm{i}^{\text {th }}$ species in the sample ( $\left.\frac{\text { No.ofindividualspecies }}{\text { totalnumberofsamples }}\right)$

$\mathrm{H}=$ the Shannon - wiener 'index of diversity $\mathrm{S}=$ number of species or species richness

$\mathrm{H}_{\max }=$ Maximum diversity possible $\mathrm{E}=$ Eveness $=H / H$ max

Margalef's index (d) measures species richness and diversity in the community structure. The equation described by Margalef (1967) was applied in the calculation. $\mathrm{d}=\frac{S-1}{\operatorname{In}(N)} \quad$ Where: $\mathrm{d}=$ species richness index $S=$ Number of species population $\mathrm{N}=$ Total number of individual species.

\section{Statistical Analyses}

Analysis of variance (ANOVA) was used to compare the means between sites and seasons of zooplankton species and physicochemical parameters to find out if there is significant difference or otherwise. Duncan Multiple Range Test was used to separate the means. All the analyses were carried out using SPSS software (16.0 version).

\section{RESULTS}

\section{Physicochemical Parameters}

The mean monthly values of water temperature, $\mathrm{pH}$ and TDS are presented in Table 1 . The range of the water temperature was between $18.5^{\circ} \mathrm{C}$ and $28.9^{\circ} \mathrm{C}$ with the lowest value recorded in January and the highest in May. Similarly, mean water temperature during dry season (January - May) was $26.3 \pm 0.70^{\circ} \mathrm{C}$ while higher value of $27.6 \pm 0.80^{\circ} \mathrm{C}$ was recorded during wet season (June - October) as presented in Table 4. Temperature variations between seasons indicated no significant difference $(p<0.05)$. The range of $\mathrm{pH}$ values was $\mathrm{pH} 7.5-8.9$ with the lowest value recorded in June and the highest in March (Figure 3). The seasonal variation of $\mathrm{pH}$ indicated that the mean $\mathrm{pH}$ of dry season was $8.9 \pm 0.15$ while that of wet season was $8.4 \pm 1.2$. There was no significant difference recorded between the two seasons $(P<$ $0.05)$. The DO ranged between $4.8 \mathrm{mg} / \mathrm{L}$ in April and to $9.1 \mathrm{mg} / \mathrm{L}$ in January. Seasonally, the highest mean DO value during dry season was $8.9 \pm 0.42 \mathrm{mg} / \mathrm{L}$ while wet season had the least value of $8.4 \pm 0.35 \mathrm{mg} / \mathrm{L}$ (Table 4). The B.O.D mean monthly values recorded during the study period ranged between $2.2 \mathrm{mg} / \mathrm{L}$ in March and $4.9 \mathrm{mg} / \mathrm{L}$ in September (Table 2). Variation in Nitrate- nitrogen among the months revealed that August had the highest concentration of $4.78 \mathrm{mg} / \mathrm{L}$ while the least concentration was recorded in February with $0.14 \mathrm{mg} / \mathrm{L}$ (Table 3 ). Mean monthly values of Electrical Conductivity which ranged from $131.8 \mu \mathrm{S} / \mathrm{cm}$ in March to $335.7 \mu \mathrm{S} / \mathrm{cm}$ in August.
Phosphate - phosphorus concentration was observed to be higher in wet season with $1.03 \pm 0.11 \mathrm{mg} / \mathrm{L}$ and low in the dry season with $0.53 \pm 0.19 \mathrm{mg} / \mathrm{L}$. Statistically, no significant difference was observed between the seasons $(P<0.05)$. There was high concentration of Nitrate- nitrogen in wet season with $4.14 \pm 0.65 \mathrm{mg} / \mathrm{L}$ than that of dry season with $3.08 \pm 0.48 \mathrm{mg} / \mathrm{L}$ which was significantly different at $\mathrm{P}<0.05$ (Table 4). The seasonal difference for TDS indicates mean dry season values of $245.3 \pm 16.94$ $\mathrm{mg} / \mathrm{L}$ and $393.4 \pm 19.70 \mathrm{mg} / \mathrm{L}$ in the wet season (Table 4). It revealed significant differences between the two seasons at $P<0.05$. The seasonal variations in the mean BOD values indicated that dry season had $3.3 \pm$ $0.17 \mathrm{mg} / \mathrm{L}$ while wet season recorded $3.7 \pm 0.21 \mathrm{mg} / \mathrm{L}$. Statistically, there was no significant difference in DO and BOD between the two seasons $(p<0.05)$. Mean monthly values of turbidity which ranged between 16.3 NTU in March and 37.1 NTU in June. The mean value recorded during the dry season was $25.5 \pm$ $0.22 \mathrm{NTU}$ while $29.0 \pm 1.24 \mathrm{NTU}$ was recorded during the wet season (Table 4). Mean turbidity values revealed significant difference between the seasons $(p<0.05)$.

\section{Zooplankton composition}

However, with regards to zooplankton a total of 268.5org/L were recorded from sites A, B, C and D belonging to four phyla: Protozoa (4.3\%), Cladocera (42.0\%), Rotifera (29.6\%) and Copepoda with $24.1 \%$ (Figure 4). Twenty eight (28) species were recorded from sites A, dominated by Daphnia pulex with 8.4org/L and the least were Amaeba proteus, Stentor sp., Daphnia dubia, Eubosmina coregoni and Thermodiaptomus sp. each had $0.2 \mathrm{org} / \mathrm{L}$. Site B and D recorded 26 and 27 species in both sites dominated by Keratella tropica with $8.4 \mathrm{org} / \mathrm{L}$ and $6.8 \mathrm{org} / \mathrm{L}$ respectively. Site $\mathrm{C}$ was dominated by Daphnia pulex with $7.6 \mathrm{org} / \mathrm{L}$ and statistically no significant difference of zooplanktonic fauna between the sampling sites $(p<0.05)$. Cladocera was the dominant division consisting of $42.0 \%$ of the total zooplanktonic fauna identified. It was represented by twelve (12) species dominated by Daphnia pulex with $25.10 \mathrm{rg} / \mathrm{L}$ representing $9.33 \%$ while Diaphanosoma excisum was the least abundant with $0.40 \mathrm{org} / \mathrm{L}$ representing $0.14 \%$ of the zooplankton (Table 5). Cladocera had the highest abundance during wet season with $67.6 \mathrm{org} / \mathrm{L}$ and the least during dry season with $27.9 \mathrm{org} / \mathrm{L}$. The species composition of cladocera indicated significant difference between wet and dry seasons at $\mathrm{p}<0.05$ (Figure 2). Rotifera was represented by six (6) species with Brachionus dimidiatus recorded the highest percentage composition of $7.77 \%$ and the least was Keratella serrulata with $0.14 \%$. Mean seasonal species composition revealed that wet season had $48.0 \mathrm{org} / \mathrm{L}$ while $26.9 \mathrm{org} / \mathrm{L}$ was recorded during dry season. Copepoda which constitutes $24.1 \%$ of the total zooplankton composition was represented by eight species. Microcyclops varicans was the dominant species among the copepod with $5.38 \%$ while Thermodiaptomus sp. and Canthocamptus sp. were the least with each $0.22 \%$ (Table 5 ). 
Bajopas Volume 10 Number 1 June, 2017

Seasonal variation revealed that wet season had the highest species composition of $35.9 \%$ while $15.1 \mathrm{org} / \mathrm{L}$ was recorded during dry season. Statistically significant difference was recorded between the two seasons $(p<0.05)$. Protozoa which constituted $4.3 \%$ of the total zooplanktonic fauna was represented by six species. Arcella sp. was the most abundant with 4.6org/L representing $1.71 \%$ while Pleuronema sp. was the least abundant with $0.20 \mathrm{org} / \mathrm{L}$ representing $0.07 \%$. Generally, seasonal variation of zooplankton species indicated that more plankton species recorded during wet season than during dry season (Figure 2).

\section{Biotic Indices}

Analysis of the zooplankton community structure to determine their abundance, evenness and diversity using biotic indices revealed that Shannon- wiener diversity Index had the highest value at site B with 1.24 while the least value for Shannon wiener was recorded site A with 1.00 (Table 6). Evenness Index (E) was highest at site $B$ and the least was at site $A$. Margalef's Index (d) which measures species richness and diversity in a community indicated the highest value at site $C$ with 6.82 and the least was site $B$ with 5.95 (Table 6). Seasonal variation with respect to biotic indices indicated that Shannon wiener Index, Evenness Index and Margalefe's Index had the following values for dry season $1.12,0.81$ and 5.65 while $1.17,0.84$ and 5.72 were recorded during the wet season (Table 4). Seasonal variation in zooplankton taxa indicated that more species richness and abundance during wet season than during dry season.

Table 1: Mean Monthly Values of Temperature, pH and Total Dissolved Solids from Thomas Dam Dambatta, Kano (January - October 2016)

\begin{tabular}{lcclccccccccc}
\hline $\begin{array}{l}\text { Month/ } \\
\text { Site }\end{array}$ & A & B & C & D & A & B & C & D & A & B & C & D \\
\hline January & 18.5 & 18.8 & 18.8 & 19.2 & 7.5 & 7.6 & 7.6 & 7.6 & 141.0 & 140.0 & 145 & 145.0 \\
February & 20.3 & 20.3 & 21.5 & 20.8 & 7.7 & 7.8 & 7.8 & 7.5 & 167.8 & 164.6 & 165.3 & 263.9 \\
March & 26.7 & 26.6 & 25.8 & 27.1 & 8.1 & 8.4 & 7.7 & 7.8 & 141.8 & 136.3 & 139.4 & 135.0 \\
April & 27.6 & 27.5 & 27.6 & 28.3 & 8.4 & 7.9 & 7.9 & 8.2 & 145.8 & 152.1 & 147.5 & 137.1 \\
May & 26.6 & 28 & 26 & 28.9 & 7.9 & 8.3 & 8.3 & 8.2 & 17.1 & 166.7 & 163.3 & 190.7 \\
June & 24.8 & 24.7 & 24.4 & 24.8 & 8.2 & 8.1 & 8.1 & 7.9 & 170.0 & 180.0 & 380.5 & 290.0 \\
July & 26.2 & 24.1 & 24.2 & 24.3 & 8.4 & 8.8 & 8.7 & 8.6 & 295.5 & 220.1 & 233.1 & 231.6 \\
August & 25.7 & 25.7 & 25.8 & 25.2 & 8.6 & 8.1 & 7.8 & 8.2 & 211.6 & 255.1 & 235.7 & 276.8 \\
September & 24.6 & 23.9 & 23.6 & 24.3 & 8.5 & 8.9 & 8.7 & 9.2 & 240.0 & 243.0 & 240.0 & 265.0 \\
October & 24.8 & 22.3 & 24.2 & 24.8 & 8.1 & 8.6 & 8.4 & 8.4 & 218.3 & 216.6 & 216.8 & 245.1 \\
Mean & $\mathbf{2 5 . 9}$ & $\mathbf{2 4 . 6}$ & $\mathbf{2 6 . 9}$ & $\mathbf{2 7 . 7}$ & $\mathbf{8 . 6}$ & $\mathbf{8 . 2}$ & $\mathbf{8 . 1}$ & $\mathbf{8 . 7}$ & $\mathbf{2 6 4 . 8}$ & $\mathbf{2 8 7 . 4}$ & $\mathbf{3 8 6 . 6}$ & $\mathbf{2 9 7 . 9}$ \\
I S.D & $\mathbf{2 . 5 3}$ & $\mathbf{2 . 3 3}$ & $\mathbf{2 . 2 1}$ & $\mathbf{2 . 2 4}$ & $\mathbf{0 . 5 6}$ & $\mathbf{0 . 4 3}$ & $\mathbf{0 . 4}$ & $\mathbf{0 . 5}$ & $\mathbf{6 2 . 2 3}$ & $\mathbf{4 3 . 0 8}$ & $\mathbf{4 0 . 6 3}$ & $\mathbf{5 3 . 5 9}$ \\
\hline
\end{tabular}

Table 2: Mean Monthly Values Dissolved Oxygen, Biochemical Oxygen Demand and Turbidity from Thomas Dam Dambatta, Kano (January - October 2016)

\begin{tabular}{|c|c|c|c|c|c|c|c|c|c|c|c|c|}
\hline \multirow{2}{*}{ Month/Sit } & \multicolumn{4}{|c|}{$\begin{array}{l}\text { Dissolved } \\
\text { Oxygen(mg/L) }\end{array}$} & \multicolumn{3}{|c|}{$\begin{array}{l}\text { Biochemical Oxygen } \\
\text { (mg/L) }\end{array}$} & \multicolumn{5}{|l|}{ Demand } \\
\hline & A & B & C & D & $\mathbf{A}$ & B & C & D & $\mathbf{A}$ & B & C & D \\
\hline January & 9.1 & 8.9 & 8.9 & 9.1 & 3.6 & 4.6 & 3.9 & 2.8 & 27.3 & 30.5 & 27.6 & 27.5 \\
\hline February & 6.3 & 8.9 & 5.7 & 7.1 & 4.3 & 4.3 & 4.2 & 3.6 & 29.5 & 26.6 & 25.5 & 27.8 \\
\hline March & 5.9 & 6.2 & 8.9 & 6.3 & 3.9 & 2.8 & 2.2 & 2.5 & 19.1 & 16.3 & 17.6 & 20.8 \\
\hline April & 6.1 & 5.3 & 5.3 & 4.8 & 2.6 & 3.3 & 2.7 & 2.9 & 24.7 & 23.5 & 23.5 & 23.6 \\
\hline May & 5.9 & 5.6 & 5.5 & 5.9 & 3.5 & 3.6 & 2.6 & 2.2 & 28.5 & 27.0 & 32.4 & 27.5 \\
\hline June & 5.7 & 5.6 & 6.4 & 5.9 & 3.1 & 3.8 & 2.7 & 3.7 & 25.0 & 27.8 & 26.1 & 27.1 \\
\hline July & 6.8 & 5.8 & 5.7 & 5.2 & 3.4 & 3.1 & 3.3 & 2.8 & 30.3 & 30.1 & 28 & 29.0 \\
\hline August & 6.9 & 6.7 & 6.4 & 5.8 & 3.8 & 3.1 & 3.7 & 3.6 & 33.3 & 29.8 & 32 & 29.3 \\
\hline September & 6.0 & 7.4 & 7.1 & 6.5 & 4.9 & 4.8 & 4.3 & 2.8 & 30.1 & 29.8 & 30.2 & 35.8 \\
\hline October & 8.2 & 7.8 & 8.0 & 8.3 & 4.4 & 4.5 & 4.4 & 3.8 & $\begin{array}{l}26 \\
27 .\end{array}$ & $\begin{array}{l}26.1 \\
26 .\end{array}$ & $\begin{array}{l}29.6 \\
27 .\end{array}$ & $\begin{array}{l}27.5 \\
27 .\end{array}$ \\
\hline Mean & $\begin{array}{l}6.9 \\
1.1\end{array}$ & 6.8 & 6.7 & 6.4 & 3.7 & 3.7 & 3.4 & 3.1 & $\begin{array}{l}4 \\
3.9\end{array}$ & $\begin{array}{l}7 \\
4.2\end{array}$ & $\begin{array}{l}2 \\
4.4\end{array}$ & $\begin{array}{l}6 \\
3.8\end{array}$ \\
\hline \pm S.D & 2 & 1.36 & 1.37 & 1.34 & 0.66 & 0.71 & 0.8 & 0.55 & 4 & 8 & 1 & 6 \\
\hline
\end{tabular}


Bajopas Volume 10 Number 1 June, 2017

Table 3: Mean Monthly Values of Phosphate, Nitrate and Electrical Conductivity from Thomas Dam Dambatta, Kano (January - October 2016)

\begin{tabular}{|c|c|c|c|c|c|c|c|c|c|c|c|c|}
\hline \multirow[b]{2}{*}{$\begin{array}{l}\text { Month/ } \\
\text { Site }\end{array}$} & \multirow[b]{2}{*}{$\mathbf{A}$} & \multirow[b]{2}{*}{ B } & \multicolumn{2}{|c|}{$\begin{array}{l}\text { Phosphate } \\
(\mathrm{mg} / \mathrm{L})\end{array}$} & \multirow[b]{2}{*}{ A } & \multicolumn{2}{|c|}{$\begin{array}{l}\text { Nitrate } \\
\text { (mg/L) }\end{array}$} & \multirow[b]{2}{*}{ D } & \multirow{2}{*}{$\begin{array}{l}\text { Electrical } \\
(\mu \mathrm{S} / \mathrm{cm}) \\
\text { A }\end{array}$} & \multicolumn{2}{|c|}{ Conductivity } & \multirow[b]{2}{*}{ D } \\
\hline & & & C & D & & B & C & & & B & C & \\
\hline January & 0.43 & 0.22 & 0.27 & 0.28 & 1.36 & 1.35 & 1.72 & 1.14 & 167.1 & 167.9 & 171.9 & 161.6 \\
\hline February & 0.26 & 0.15 & 0.22 & 0.18 & 0.24 & 0.16 & 0.14 & 0.33 & 175.9 & 171.7 & 168.1 & 165.1 \\
\hline March & 0.38 & 0.69 & 0.72 & 0.91 & 2.92 & 2.91 & 3.41 & 3.46 & 169.8 & 131.8 & 134.8 & 137.6 \\
\hline April & 0.61 & 0.72 & 0.57 & 0.81 & 1.84 & 1.38 & 1.57 & 1.39 & 155.1 & 154.9 & 155.9 & 162.4 \\
\hline May & 0.86 & 1.45 & 1.38 & 0.44 & 3.98 & 7.21 & 3.52 & 2.09 & 177.5 & 145.5 & 176.7 & 174.9 \\
\hline June & 0.34 & 0.61 & 0.73 & 0.63 & 3.64 & 1.07 & 4.41 & 1.37 & 184.1 & 176.3 & 177 & 180.7 \\
\hline July & 0.93 & 1.35 & 1.13 & 1.89 & 2.36 & 3.96 & 2.89 & 2.09 & 230.1 & 270.9 & 303.5 & 250.8 \\
\hline $\begin{array}{l}\text { August } \\
\text { Septemb }\end{array}$ & 0.99 & 0.71 & 0.52 & 0.58 & 4.45 & 2.51 & 4.78 & 2.49 & 282.8 & 273.6 & 335.7 & 341.8 \\
\hline er & 1.41 & 1.81 & 1.65 & 1.94 & 2.98 & 3.89 & 4.28 & 4.6 & 196.7 & 190.5 & 204.5 & 297.6 \\
\hline October & $\begin{array}{l}0.41 \\
0.6\end{array}$ & $\begin{array}{l}0.65 \\
\mathbf{0 . 8}\end{array}$ & 1.43 & 1.07 & $\begin{array}{l}3.41 \\
3.5\end{array}$ & 1.36 & 3.46 & $\begin{array}{l}3.36 \\
\mathbf{2 . 2}\end{array}$ & 201.5 & 196.9 & 199.6 & $\begin{array}{l}231.8 \\
\mathbf{2 1 0} .\end{array}$ \\
\hline Mean & $\begin{array}{l}6 \\
0.3\end{array}$ & $\begin{array}{l}1 \\
0.5\end{array}$ & 0.88 & 0.95 & $\begin{array}{l}1 \\
1.0\end{array}$ & 2.62 & 4.3 & $\begin{array}{l}2 \\
1.2\end{array}$ & 194.1 & 188.3 & 202.4 & 4 \\
\hline 土 S.D & 7 & 3 & 0.5 & 0.61 & 2 & 2.05 & 1.33 & 8 & 37.67 & 48.1 & 65.45 & 67.61 \\
\hline
\end{tabular}

Table 4: Seasonal Variation of Physicochemical Parameters and Biotic Indices in Thomas Dam, Dambatta Kano (January - October, 2016)

\begin{tabular}{|c|c|c|c|}
\hline Parameters & Dry season (January- May) & Wet season (May - October) & Standard limits \\
\hline Water temperature $\left({ }^{\circ} \mathrm{C}\right)$ & $27.6 \pm 0.70$ & $26.3 \pm 0.80$ & $<40^{\circ} \mathrm{Cmg} / \mathrm{L}^{*}$ \\
\hline $\mathrm{DO}(\mathrm{mg} / \mathrm{L})$ & $7.8 \pm 0.42$ & $6.6 \pm 0.35$ & $5.0-9.0 \mathrm{mg} / \mathrm{L}^{* *}$ \\
\hline $\begin{array}{l}\text { BOD }(\mathrm{mg} / \mathrm{L}) \\
\text { TDS }(\mathrm{mg} / \mathrm{L})\end{array}$ & $\begin{array}{l}3.3 \pm 0.17 \\
245.3 \pm 16.94\end{array}$ & $\begin{array}{l}3.7 \pm 0.21 \\
393.4 \pm 19.70\end{array}$ & $\begin{array}{l}3.0-6.0 \mathrm{mg} / \mathrm{L}^{* *} \\
<500 \mathrm{mg} / \mathrm{L}^{* * *}\end{array}$ \\
\hline $\begin{array}{l}\text { Electrical Conductivity } \\
(\mu S / c m)\end{array}$ & $181.4 \pm 21.38$ & $161.3 \pm 11.91$ & $<1000 \mu / \mathrm{Scm}^{* *}$ \\
\hline Turbidity (NTU) & $26.5 \pm 1.22$ & $32.0 \pm 1.24$ & $<25$ NTU** \\
\hline $\mathrm{pH}$ & $8.9 \pm 0.15$ & $8.4 \pm 0.12$ & $6.0-9.0 *$ \\
\hline Phosphate (mg/L) & $0.53 \pm 0.19$ & $1.03 \pm 0.11$ & $0.1 \mathrm{mg} / \mathrm{L}^{* *}$ \\
\hline $\begin{array}{l}\text { Nitrate }(\mathrm{mg} / \mathrm{L}) \\
\text { Shannon - wiener index }(\mathrm{H}) \\
\text { Evenness index }(\mathrm{E}) \\
\text { Margalef's index }(\mathrm{d})\end{array}$ & $\begin{array}{l}3.08 \pm 0.40 \\
1.17 \\
0.84 \\
5.72\end{array}$ & $\begin{array}{l}4.14 \pm 0.65 \\
1.12 \\
0.81 \\
5.56\end{array}$ & $5 \mathrm{mg} / \mathrm{L}^{* * *}$ \\
\hline
\end{tabular}

*FEPA (1991), **FME (2001), ***WHO (2003)

Table 5: Zooplankton Composition, Distribution and Relative Abundance in Thomas Dam, Dambatta, Kano (January - October, 2016)

\begin{tabular}{lllllll}
\hline Species composition (org/L)/Site & A & B & C & D & Total & Frequency (\%) \\
\hline Protozoa & & & & & & \\
Amoeba proteus & 0.2 & 2.6 & 0.8 & 0.2 & 3.8 & 1.37 \\
Arcella sp. & 1.2 & 1.2 & 1.0 & 1.2 & 4.6 & 1.71 \\
Stentor sp. & 0.2 & 0.2 & 0.4 & 0.0 & 0.8 & 0.29 \\
Vorticella sp. & 0.4 & 1.0 & 0.4 & 0.0 & 1.8 & 0.66 \\
Pleuronema sp. & 0.0 & 0.0 & 0.2 & 0.0 & 0.2 & 0.07 \\
Pelomyxa sp. & 0.2 & 0.2 & 0,0 & 0.0 & 0.4 & 0.14 \\
Cladocera & & & & & & \\
Daphnia pulex & 7.3 & 4.6 & 7.6 & 5.6 & 25.1 & 9.33 \\
D. dimidiatus & 0.4 & 1.6 & 0.4 & 1.8 & 4.2 & 1.56 \\
D. longiremis & 8.2 & 4.0 & 4.0 & 5.2 & 21.4 & 7.96 \\
D. dubia & 0.2 & 0.2 & 0.4 & 0.0 & 0.8 & 0.29 \\
D. retrocurva & 8.4 & 7.9 & 1.4 & 5.6 & 23.3 & 8.35 \\
Bosmina rostrum & 3.2 & 4.0 & 4.8 & 4.6 & 16.6 & 6.21 \\
B. meridionalis & 1.2 & 0.4 & 1.2 & 0.3 & 3.1 & 1.15 \\
B. longirostris & 7.5 & 1.2 & 3.2 & 2.0 & 8.4 & 3.12 \\
Eubosmina corigoni & 0.2 & 0.0 & 0.0 & 0.4 & 0.6 & 0.22 \\
Monostyla lunaris & 1.2 & 0.6 & 0.6 & 0.4 & 3.6 & 1.34 \\
\hline
\end{tabular}


Bajopas Volume 10 Number 1 June, 2017

Table 5 continue

\begin{tabular}{lllllll}
\hline Species composition (org/L)/Site & A & B & C & D & Total & Frequency (\%) \\
\hline Moina micrura & 0.0 & 0.2 & 0.6 & 0.2 & 0.8 & 0.29 \\
Diaphanosoma excisum & 0.0 & 0.0 & 0.2 & 0.2 & 0.4 & 0.14 \\
Rotifera & & & & & & \\
Brachionus caudatus & 4.9 & 0.2 & 0.6 & 0.8 & 6.5 & 2.78 \\
B. dimidiatus & 6.8 & 3.8 & 4.5 & 5.8 & 20.9 & 7.77 \\
B. falcatus & 3.2 & 4.8 & 4.4 & 4.3 & 16.7 & 6.19 \\
B. dichotomus & 3.4 & 2.6 & 3.6 & 2.4 & 12 & 4.46 \\
Keratella tropica & 1.4 & 8.4 & 3.8 & 6.8 & 16.6 & 6.45 \\
K. serrulata & 0.2 & 0.0 & 0.0 & 0.2 & 0.4 & 0.14 \\
Copepoda & & & & & & \\
Diaptomus sp. & 1.2 & 3.0 & 3.6 & 3.4 & 11.2 & 4.16 \\
Microcyclops varicans & 3.6 & 4.2 & 3.0 & 3.7 & 14.5 & 5.38 \\
Tropocyclops confinis & 3.8 & 2.8 & 1.4 & 2.6 & 10.6 & 3.91 \\
Thermodiaptomus sp. & 0.2 & 0.0 & 0.0 & 0.4 & 0.6 & 0.22 \\
Cyclops sp. & 4.2 & 0.4 & 0.6 & 6.0 & 11.2 & 4.17 \\
Canthocamptus sp. & 0.0 & 0.0 & 0.6 & 0.0 & 0.6 & 0.22 \\
Mesocyclops sp. & 0.0 & 0.0 & 1.6 & 1.4 & 5.0 & 1.86 \\
Thermocyclops crassus & 1.8 & 0.6 & 0.2 & 0.4 & 3.0 & 1.11 \\
Nauplius of copepod & 6.4 & 3.8 & 4.8 & 3.8 & 18.8 & 6.99 \\
No. of individals (ogr/L) & 80.9 & 64.5 & 59.9 & 69.7 & 268.5 & 100.00 \\
Number of species per site & 28 & 26 & 29 & 27 & & \\
Shanno-diversity (H) & 1.00 & 1.24 & 1.17 & 1.13 & & \\
Evenness (E) & 0.72 & 0.89 & 0.85 & 0.81 & & \\
Margalef's Index (d) & 6.13 & 5.95 & 6.82 & 6.13 & & \\
\hline
\end{tabular}

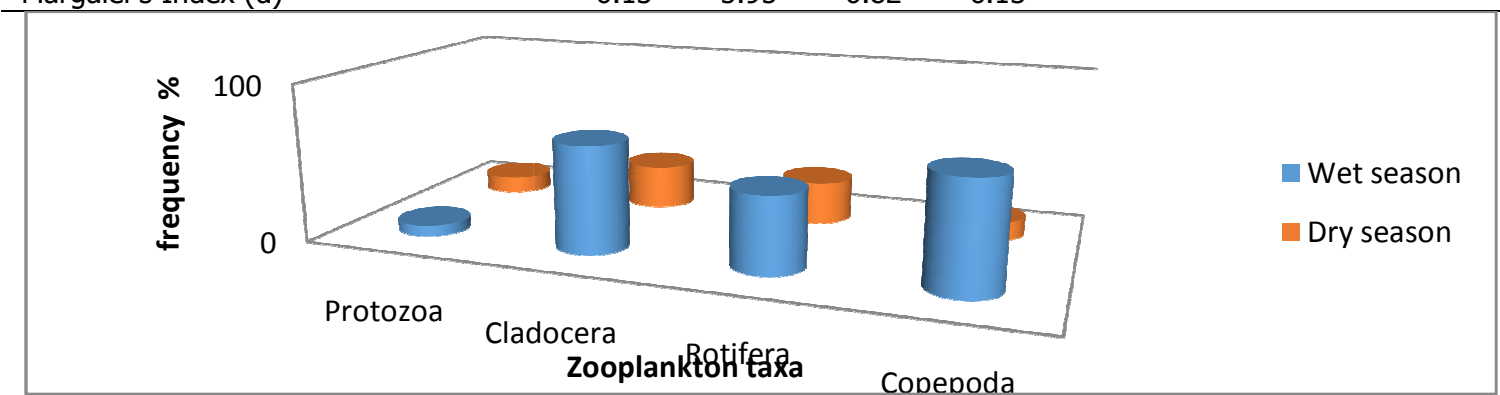

Fig 2: Seasonal Comparison of Zooplankton Composition from the Sampling Sites in Thomas Dam (January- October, 2016)

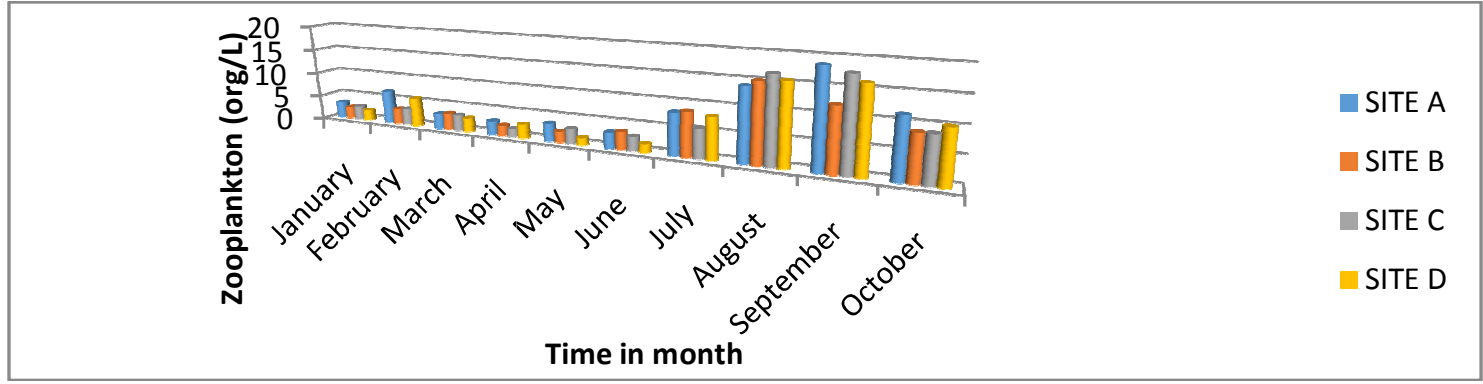

Fig. 3: Mean Monthly Variation of Zooplankton in Thomas Dam Dambatta, Kano (Jan. - Oct. 2016)

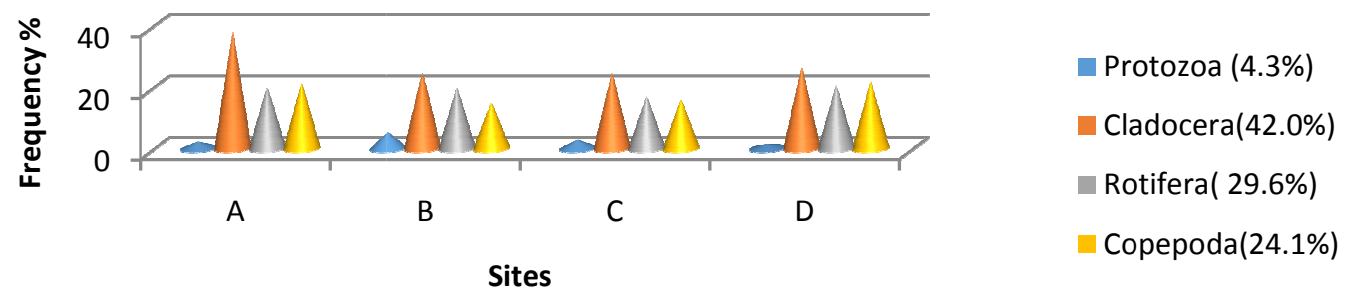

Fig. 3Variation of Zooplankton Taxa across the Sampling sites at Thomas Dam Dambatta, Kano (January- October, 2016) 


\section{DISCUSSION}

Zooplankton species abundance in a water body depends on whether it can tolerate the water and flourish in the system (Balarabe, 2001).Dejen et al. (2004) pointed out that various physicochemical and biological circumstances must be simultaneously taken into consideration for understanding fluctuation of biological population in water body. In Thomas Dam Dambatta, limnological variables were observed to fluctuate slightly during the study period, across the physical parameters which include depth, temperature and turbidity. These parameters varied gradually from January to October. The mean monthly values for the physicochemical parameters were presented in Table 1 - 4. During the study period, mean water temperature of the dam fluctuate between $18.5-28.9^{\circ} \mathrm{C}$. The low water temperature recorded in the January, might be due to the characteristic cool dry North-East trade wind (Harmattan) between December and February while the relatively high water temperature in May was due to characteristic of hot weather in Kano. This trend of temperature variation is in tandem with the findings of Ezra and Nwankwo (2001) in Gubi Reservoir, Inuwa (2007) in Jakara Dam, Adakole et al. (2008) in Kubanni Lake, Ibrahim (2009) in Challawa, River Kano State and Kefas et al. (2015) in Lake Geriyo, Adamawa State. The pH value recorded in this study $(7.5-8.9)$ was observed to increase slightly from January to October. The $\mathrm{pH}$ recorded fall within the acceptable limits of 6.5- 8.5 for fresh water bodies set by National Standard for Drinking Water Quality (2007). TDS in water consist of inorganic salts and dissolved materials and high values of TDS may lead to change in water taste (Pandey, 1997). The TDS values recorded in the dam varied from $140 \mathrm{mg} / \mathrm{L}$ to $386.6 \mathrm{mg} / \mathrm{L}$. This falls within the maximum limit of $600 \mathrm{mg} / \mathrm{L}$ set by FEPA (1991). In the present investigation, Dissolved Oxygen ranged between 4.8$9.1 \mathrm{mg} / \mathrm{L}$, which is quite satisfactory to support aquatic life perhaps due to good aeration rate and photosynthetic activity as reported byMohammed and Saminu (2012). The distribution of Dissolved Oxygen in water body has been reported to be governed by a balance between input from the atmosphere, rainfall, photosynthesis and losses by the chemical and biotic oxidations Surajit and Tapas (2014). Turbidity of the water body also varied significantly according to the season it ranged from $25.5 \pm 0.22 \mathrm{NTU}$ $29.0 \pm 1.24$ NTU during dry and wet season respectively. The water turbidity during wet season might be related to cloudiness of water body as a result of particulate matter being suspended within it (Kutama et al., 2013). Phosphates- phosphorus ranges between $0.15-1.13 \mathrm{mg} / \mathrm{L}$ and Nitrate- nitrogen with $0.14-4.78 \mathrm{mg} / \mathrm{L}$. The values recorded were higher than the standard limit for fresh water set by FEPA (1991).This corroborates with the findings of Umar and Bashir (2014) who recorded higher values of both nitrate and phosphate in their work on seasonal comparism of physicochemical parameters in Thomas Dam, Kano State. The higher values of phosphate and nitrate concentrations could be attributed to the inputs from agricultural activities around the study area. The values recorded were higher than what was reported by Kefas et al. (2015) in Lake Geriyo, Adamawa state, Nigeria.

The zooplankton was dominated by Cladocerans represented by Daphnia pulex (9.33org/L) and was Diaphanosoma excisumwith $0.07 \mathrm{org} / \mathrm{L}$. The dominant of Cladocerans in the Dam may be attributed to their habitat of being cosmopolitan in the tropical region (Abdulazeez, 2015). The dominance of Daphnia sp. has been reported by Bala and Bolorunduro (2011) in Sabke Reservoir Katsina State. The dominance of Daphnia sp. and Bosmina sp. agrees with the fact that the species are the most widely and frequently recorded planktonic species in the open water habitat (Lynne, 2004). It could also be due to its large body size which enables it to graze on large quantities and diverse forms of phytoplankton. The density and biomass of Cladocera were primarily determined by food supply (Imoobe et al., 2008). The rotifers species identified during the study period had $76.7 \mathrm{org} / \mathrm{L}$ representing $29.6 \%$ of the zooplanktonic fauna. Rotifera represented by six (6) species with Brachionus caudatus, B. dimidiatus, B. falcatus, B. dichotomus, Keratella tropica and $K$. serrulata. B. dimidiatus had the highest percentage composition of $7.71 \%$ and the least was Keratella serrulata with $0.14 \%$. The high species diversity identified could be due to their characteristic of being prevalent in fresh waters as reported by Brummett (2000). Rotifers are also cosmopolitan in nature andmajority is highly adapted to a wide range of freshwater conditions (Hutchinson, 1967). Edema et al. (2002) reported that numerically the rotifers constituted $(72.60 \%)$ of plankton during an earlier preliminary studies of zooplankton of Okhuo River. The large number of smaller zooplankton species in the case of Rotifers may possibly be due to predation pressure from planktivorous fishes that selectively prey on larger sized zooplankton (Imoebe and Adeyinka, 2010). Rosemond et al. (1993) says that ability to adapt to food conditions and less predation may be the reasons for the significant abundance of rotifers, cladocera and copepods in the many tropical water bodies. High number of rotifers could also be due to their short generation time and parthenogenetic reproduction pattern. Similar observation was also made by Akin-oriola (2003) and Mustapha (2008)that rotifers were the dominant zooplankton group in Nigerian aquatic ecosystem. The relative abundance of copepods with $24.1 \%$ was as a result of the prevailing physicochemical parameters of the Dam that favours their reproductive cycle as reported byAbdulazeez (2015). The low genera abundance of copepods identified compared to cladocera and rotifera could be due to their slow reproduction, growth and renewal rate and absence of parthenogenetic forms of copepods might be responsible for their low population density. This was similar to what was observed by Mustapha (2008) in Oyun Reservoir Offa, Nigeria. Thirty two (32) species of zooplankton were identified during this study which is higher than what was recorded by Balarabe (2001) who identified twenty (20) species of zooplankton in Zaria Dam, Kaduna State. Ibrahim (2009) also identified eighteen (18) zooplankton species in Challawa River Kano.The present study also corroborates with findings of Kutama et al (2010) in Kusalla Reservoir Kano State.

Moreover, with respect to sites, site $\mathrm{A}$ is characterised to have more abundance of the zooplankton species than site $B, C$ and $D$ because at this point irrigation activities take place during the dry season and vegetations are subjected to chemicals input from fertilizer application.Daphnia retrocurva and Daphnia pulex were abundant in site A than any other sites this may due to their large bodies and high resistant to disturbance of human and other domestic activities as reported by Akin - Oriola(2003).The above observation conforms to the report of Ovie (1995) and Okogwu and Ugwumba (2006) that plankton maxima may occur at any time of the year in the tropics depending on the condition of the ecosystem. The present study revealed that physicochemical factors affected the composition and abundance of zooplankton as reported by Hanazato (2001) and Saidu et al. (2009) that chemical condition of aquatic environment determine species richness, average size of the organism, energy flow transfer efficiency, food web complexity and length of food chain. Mean seasonal variation of the zooplankton fauna had its highest composition during wet season with $18.6 \mathrm{org} / \mathrm{L}$ and lowest in dry season with 1.4org/L (Table 4). Taxa variation revealed the following values of zooplankton in wet season; protozoa $(3.7 \%)$, cladocera $(35.6 \%)$, rotifera $(26.2 \%)$ and copepod $(34.5 \%)$ while in dry season $14.6 \%, 38.8 \%, 30.5 \%$ and $15.8 \%$ were recorded for protozoa, cladocera, rotifera and copepoda respectively. Their abundance in wet season could be due to availability of nutrients and high population of phytoplankton which were highly abundant within the Dam during the wet season. This is tandem with finding of Rocha et al. (1999) that increase in primary production (phytoplankton) tends to 


\section{Bajopas Volume 10 Number 1 June, 2017}

be followed by increase in zooplankton number and abundance. This also corresponds with the study of Ibrahim (2008) that plankton usually reaches their peak source, low predation by fish during the wet season as a result of their breeding which could also encouraged high population of the zooplankton

With respect to biotic indices Margalef's Index site $\mathrm{C}$ had the highest value of 6.82 which showed higher species diversity among the sites when compared with site A with 6.13 , B (5.92) and C (6.13). Shannon-Weiner's and Evenness Indices were high in the wet season than in the dry season (Table 5). Margelef's index is higher in the wet season than in the dry season. The high value recorded in wet season recorded in the present study is in tandem with the findings of Thirupathaniah et al. (2001). The diversity indices computed were across all the sites and did not vary among sampling sites $(p<0.05)$. This is in agreement with the earlier position of Imoebe and Adeyinka (2010) in Okhuo water body.

\section{CONCLUSION AND RECOMMENDATION}

During the study period Thomas Dam appeared to have high zooplankton species composition and abundance during wet

\section{REFERENCES}

Abubakar, M.M, Balarabe, M.L and Auta, J. (2012). Effects of Physico-chemical Factors on Seasonal Dynamics of the Phytoplankton in Nguru Lake. Northeastern Nigeria. Journal of Natural Sciences Research, 2(8): 74-81.

Abdulazeez, M.T. (2015).Limnological Studies of Karidna Reservoir in Igabi Local Government area of Kaduna State, Nigeria.M.Sc. Thesis Ahmadu Bello University, Zaria. Pp. 68.

Adakole, J.A., Abolude, D.S. and Balarabe, M.L. (2008). Assessment of Water Quality of a Man-Made Lake in Zaria, Nigeria. Proceedings of Taal: The 12th World Lake Conference: 1373-1382.

Adesalu, T.A. and Nwankwo, D. I. (2010). Cyanobacteria of a Tropical Lagoon, Nigeria. Journal of American Science, 6(4): 74- 79.

Anene, A. (2003). Techniques in Hydrobiology. In: Eugene, N.O. and O.O. Julian, (Eds.), Research Techniques in Biological and Chemical Sciences. Springfield Publishers, pp: 174-189.

APHA. (2005).Manual of Standard Methods for Examination for Water and Waste water. 14th Edition. Washington Dc. pp. 121-132.

Bala, U. and Bolorunduro, P.1. (2011). Limnological Survey and Nutrient load of Sabke Reservoir, Katsina State, Nigeria. African Scientist, 11(3): 163-168.

Balarabe, M.L. (2001). Effect of Limnological Characteristic on Zooplankton Composition and distribution in Dumbi and Kwangila Ponds, Zaria, Nigeria. Ph.D. Thesis, Department of Biological Sciences, Ahmadu Bello University Zaria. Pp 65

Brummett, R.E. (2000). Food Organism Availability and Resource Partitioning in- Organically and Inorganically Fertilized Tilapia rendalli ponds. Aquaculture, 183 (1): 51-71.

Davies, O. A.; Abowei, J. F. N. and Otene, B. B. (2009): Seasonal abundance and distribution of plankton of Minichinda stream, Niger Delta, Nigeria. American Journal of Scientific Research, 2(2): 20-30.

Dejen, E., Vijverberg, J., Nagelkerke, L. and Sibbing, F. (2004). Temporal and Spatial Distribution of Microcrustacean Zooplankton in Relation to Turbidity and other Environmental Factors in Large Tropical Lake (L. Tana, Ethiopia). Hydrobiologia, 5(3): 39-49.

Edema, C.U.Ayeni J.O., and Aruoture A . (2002). Some Observations of the Okhuo River, Nigeria Journal of Aquatic sciences, 17(2): 145 - 149. season when compared to dry season. Seasonal climatic changes, irrigation among other domestic activities around the sampling sites influenced variations in the zooplankton composition and physicochemical characteristics of the dam. It is therefore recommended that government and nongovernmental organizations should encourage continual research on the general biology and physicochemical parameters of inland water bodies with the view of tracking and monitoring adverse environmental changes in the aquatic environment like Thomas Dam Dambatta in Kano, Nigeria.

\section{ACKNOWLEDGMENT}

The authors hereby acknowledge Dr. Isa Yunusa of Kano University of Science and Technology Wudil, Kano for the Statistical analysis. Mal.Umar Sani Dorayi, Mal. Idris Bala of Microbiology Department, Bayero University Kano, and Mal. Nura Usman of Science Laboratory Technology Department, Kano State Polytechnic, are hereby acknowledged for organizing the draft manuscript and providing technical assistance for the work, respectively.

\section{CONFLICT OF INTEREST}

The authors declared that they have no conflict of interest

Ekwu, A. O. and Sikoki, F. D. (2005). Species Composition and Distribution of Zooplankton in the Lower Cross River Estuary. www.uniportjournals.com/ajazeb/2005 /02\%Alice\%20zooplankton.htm. Accessed on 23/8/2016.

Ezra, A.G. and Nwankwo, D.I. (2001). Composition of Phytoplankton Algae in Gubi Reservoir, Bauchi, Nigeria. Journal of Aquatic Science, 16(2): 115 - 118.

FEPA (1991). National Environmental Protection (Effluent Limitation) Regulations of $1991 . \quad$ Federal Environmental Protection Agency, Lagos, Nigeria. Pp.1-8.

FME (Federal Ministry of Environment). (2001). Guidelines and Standard for Quality in Nigeria. Published Federal. Ministry of Environment, p.114.

Food and Agriculture Organisation (FAO). (2006). Interrelationship between Fish and Plankton in Inland Water. Retrieved from http.//w.w.w.fao.org/DocREP/006. Accessed on September 29, 2016.

Goswami, S.C. (2004). Zooplankton Methodology Collection and Identification - a Field Manual: National Institute of Oceanography, Dona Paula, Goa- 403004 Pp5-8.

Hassan, K. Y., Kutama, A.S, Halima, B., Maryam, T. A, Indabawa, I.I.and Sani, I. (2013).Studies on the Biodiversity of Phytoplanktons andZooplanktons of Kanye Dam in Kano State:Research Journal of Agriculture and Environmental Management. 2(10): 312-322.

Hassan, F. M., Kathim, F. N., and Hussein, H. F. (2004). Effect of Chemical and Physical Properties of River Water in Shatt al-hilla on Phytoplankton Communities. E. Journal of Chemistry, 5(3): 323-330.

Hanazato, T. (2001). Pesticide Effects on Freshwater Zooplankton: An Ecological perspective. Environmental Pollution, 112(2): 1-10. 262.

Hutchinson, G.E. (1967). A Treatise on Limnology Vol. 11. Introduction to Lake Biology and the Limnoplankton. John Wiley and sons. Inc. New York, Pp 1115.

Hutchinson, E.A. (1970). A study of Planktonic Rotifer of River Ganard, Essex Ontario, M.Sc. Thesis University of windsov, Ontario Canada Pp 58-86.

Ibrahim, S. (2008). Effect of Lead on Zooplankton Dynamics in Challawa River, Kano State, Nigeria. Bayero Journal of Pure and Applied Sciences, 1(1): 88-94.

Ibrahim, S. (2009). A Survey of Zooplankton Diversity of Challawa River, Kano and Evaluation of Some of its Physico-chemical Conditions. Bayero Journal of Pure and Applied Sciences, 2(1):19-26. 
Bajopas Volume 10 Number 1 June, 2017

Imam, T.S and Balarabe M.L. (2012). Impact of Physicochemical Factors on Zooplankton Species Richness and Abundance in Bompai-Jakara Catchment Basin, Kano State Nigeria. Bayero Journal of Pure and Applied Sciences,5(2):34-40.

Inuwa, B. (2007). Studies on Aspects of Physicochemical Conditions and the Fish Biology in Jakara Dam, Kano, Nigeria. M.Sc. Dissertation Submitted to the Biological Sciences Department, Bayero University, Kano. pp56.

Imoobe, T. O. T., Tawari-Fufeyin P. and Ejoh, A. S. (2008). Community Structure of Crustacean Zooplankton in Ekpan Creek, a Perturbed Tributary of Warri River, Niger Delta, Nigeria. African Scientist Vol. 9(4):123 134.

Imoobe, T. O. T. and Adeyinka, M. L. (2010). ZooplanktonBased Assessment of the Trophic State of a Tropical Forest River. International Journal of Fisheries and Aquaculture, 2(2): 64-70.

Jeje, C.Y. and Fernando, C.K. (1982). A Practical guide to the identification of Nigeria Zooplankton Kainji Lake, Institute of Applied Sciences, 2(1): 19 - 26.

Kefas. M, Abubakar. K.Aand Ali.J. (2015).The Assessment of Water Quality via Physicochemical Parameters and Macro Invertebrates in Lake Geriyo, Yola, Adamawa State, Nigeria. The International Journal of Science \& Technoledge, 3 (3): 284- 290.

Kusuma, M. S., Neelakanton, B. and Konnur, R. G. (1988). Plankton Distribution in the Kali Estuary, Karwar Central West Coast of India, Environmental and Ecology, 1(1): $115-119$.

Kutama, R.M., Balarabe, M.L and Indabawa, I.I. (2010). The Influence of Physico-Chemical Parameters on the Zooplankton Distribution of Kusalla Reservoir, Kano State. Bayero Journal of Pure and Applied Sciences, 4(2): $87-90$.

Kutama, A.S., Umar, S., Fagwalawa, L.D, Ahmed, M.K and Bilkisu, A.I. (2013). Detection of Fish Saprolegniasis in Thomas Dam and Challawa Commercial Fish Pond:Global Advanced Research Journal of Agricultural Science, 2(12):315-321.

Kutama, R.M; Mohammad, M. A and Mohammad; M.L.(2014).The Plankton as Indicators of Water Quality in Kusalla Reservoir: A shallow Man Made Lake. Journal of Pharmarcy and Biological Sciences, 9(3):12-15.

Lamai, S.L and Kolo R.J (2003) Biodiversity in Dan- Zaria Dam, Niger state. Nigeria Journal of Aquatic Sciences, 18(2): 140-148.

Lynne, M. W. (2004). Aquatic Invertebrate Taxonomist, Cooperative Freshwater Ecology Unit, $2^{\text {nd }}$ edition, $\begin{array}{llll}\text { Laurentian University pp } & 32 & -44\end{array}$ http://coopunit.laurentian.ca.

Margalef, R. (1967). Diversity and Stability: A practical Proposal and a Model of Interdependence. Brookhaven Symposium on Biology; 22(1): 25-37.

Mustapha, M.K. (2008). Assessment of the Water Quality of Oyun Reservoir, Offa, Nigeria, using Selected Physico-chemical Parameters. Turkish Journal of Fisheries and Aquatic Sciences, 8(1): 309-319.

Mohammed, M. A. and Saminu M.Y. (2012). Water Quality and Phytoplankton of Salanta River Kano, Nigeria. Journal of Biological Science and Bioconservation, (4):65-73.

Moore, M. L. (1989): NALMS Management Guide for Lakes and Reservoirs. North American Lake Management Society (http: www.nalms.org).

Nigerian Standard for Drinking Water Quality NSDWQ (2007): Nigerian Industrial Standard. NIS 554, Standard Organization of Nigeria. Lagos. Pp 30.

Nlewadim, A. A. and Adeyemo, A. A. (1998): Effect of Inorganic Fertilization on Zooplankton Production in Brackish Water (ed.). Selected Papers from 9th/10th Annual Conference of the Nigerian Association for
Aquatic Sciences.Theme: Sustainable Utilization of Aquatic/wetland Resources, held at University of Agriculture, Abeokuta, Ogun State, Nigeria, 30th November - 2nd December, 1995. P.75-82.

Ovie, S.I. (1995). Zooplankton Species Richness and Sorenson's Index of Similarity for Asa Lake and some other Freshwater Ecosystem in Nigeria. National Institute for Freshwater Fisheries annual report. Pp 57-62.

Okogwu, O. I. and Ugwumba, O. A. (2006). The Zooplankton and Environmental Characteristics of Ologe Lagoon, South West Nigeria. The Zoologist, 1(4): 86- 92.

Pandey, G.N. (1997).Environmental Management. Vikas Publishing House, New Delhi, India. P: 33-37.

Rocha,O.T, Matsumura-Tundisi., E.L.G. Espindola., K.F. Roche and A.C. Rietzler (1999). Ecological Theory Applied to Reservoir Zooplankton, Pp 29-51. In Tundisi, J.G and M. Straskraba (eds.). Theoretical Reservoir Ecology and its Applications. International Institute of Ecology, Brazilian Academy of Sciences. Backhuys Publishers, Leiden, Holland. pp 124.

Rosemond, A.D; Mulholl, P and Elwood, J.W (1993). Topdown and Bottom-up control of stream periphyton: effects of nutrients and herbivores. Ecology, 74:1264- 1280

Saidu, A. K.; Agbelege, O. O.; Ahmed, M. T. and Olanrewaju, A. N. (2009). Some Water Quality Parameters and Zooplankton Periodicity of the Baga in-take Channel of Lake Chad. Proceedings of FISON, 1(1): 105-107.

Sanet, J.V; Jonathon,T; Carin, V.G and Annelise, G. (2006). Easy Identification of the Common Fresh Algae: $A$ Guide for the Identification of Microscopic Algae in Southern Fresh Waters, North West University, Potchefsroom, Pretoria. Pp 31- 44.

Suresh, S; Thirumala, S. and Ravind, H. (2011): Zooplankton Diversity and its Relationship with Physico-chemical Parameters in Kundavada Lake, of Davangere District, Karnataka, India. Pro Environment, 4(1): 56 -59 .

Suthers, I.M. and Rissik, D. (2009). Plankton: $A$ Guide to their Ecology and Monitoring for Water Quality. CSIRO Publishing, Collingwood, Vic., Pp: 272.

Surajit, M. and Tapas. D. (2014). Studies on Seasonal Variations in Physico-chemical Parameters in Bankura Segment of the Dwarakeshwar River (W.B.) India. International Journal of Advanced Research, 2(3): 877-881. Retrieved on 26/7/2016 from http://www.journalijar.com

Shannon, C.E, and Weaver, W. (1949). The Mathematical Theory of Communication. Urban University, Illinois Press, Illinois, P. 125.

Shitu M.B. (2006). State Educational Sector Project: Institutional Assessment -Kano State, ESSPIN. Retrieved on 20-10-2016.

Thirupathaniah, M., Samatha, C.H., and Samamaih, C.H. (2001): Diversity of Zooplankton in Freshwater Lake of Kamalapur, Karimnagar district. India. The ecoscan, 5 (1):85-87.

Umar, Z.D and Bashir, A. (2014). Assesment of Potential Health Impacts on Surface Water Sources In Northern Nigeria, International Journal of Environment, 3(2): 125-136.

Wetzel, R.G and Liken,s G.E. (2000). Limnological Analyses, Third Edition. Springer, New York pp 429.

World Health Organization (2003). Guidelines for Safe Recreational Water Environment Volume 1:Coastal and Fresh Waters, Geneva, pp 1-33.

Verma, P.S. and Agarwal, V.K. (2007): Environmental Biology: Principles of Ecology. 11th reprinted edition. S.Chand and Co. Ltd. Pp 33-35.

Verlencar, X.N and Desai, S. (2004).Phytoplankton Identification Manual. National Institute of Oceanography New Delhi, $1^{\text {st }}$ ed Pp 4. 